\title{
From Machining Chips to Raw Material for Powder Metallurgy-A Review
}

\author{
Catarina Duarte Batista ${ }^{1,2} \mathbb{D}^{2}$, Adriana André Martins das Neves de Pinho Fernandes ${ }^{3}$, \\ Maria Teresa Freire Vieira ${ }^{2}$ and Omid Emadinia $4, * \mathbb{D}$
}

1 CDRSP —Centre for Rapid and Sustainable Product Development, Polytechnic Institute of Leiria, Rua General Norton de Matos, Apartado 4133, 2411-901 Leiria, Portugal; catarina.baptista@ipleiria.pt

2 CEMMPRE-Centre for Mechanical Engineering, Materials and Processes, University of Coimbra, Pinhal de Marrocos, 3030-788 Coimbra, Portugal; teresa.vieira@dem.uc.pt

3 Department of Metallurgical and Materials Engineering, Faculty of Engineering, University of Porto, 4200-465 Porto, Portugal; up201705636@edu.fe.up.pt

4 LAETA/INEGI-Institute of Science and Innovation in Mechanical and Industrial Engineering, 4200-465 Porto, Portugal

* Correspondence: oemadinia@inegi.up.pt

Citation: Batista, C.D.;

Fernandes, A.A.M.d.N.d.P.;

Vieira, M.T.F.; Emadinia, O. From Machining Chips to Raw Material for Powder Metallurgy-A Review. Materials 2021, 14, 5432. https:// doi.org/10.3390/ma14185432

Academic Editor: Irina Hussainova

Received: 12 August 2021

Accepted: 17 September 2021

Published: 20 September 2021

Publisher's Note: MDPI stays neutral with regard to jurisdictional claims in published maps and institutional affiliations.

Copyright: (c) 2021 by the authors. Licensee MDPI, Basel, Switzerland. This article is an open access article distributed under the terms and conditions of the Creative Commons Attribution (CC BY) license (https:// creativecommons.org/licenses/by/ $4.0 /)$.

\begin{abstract}
Chips are obtained by subtractive processes such as machining workpieces and until recently considered as waste. However, in recent years they are shown to have great potential as sustainable raw materials for powder technologies. Powder production from metal chips, through the application of solid-state processes, seems to be an alternative to conventional atomization from liquid cooled with different fluids. However, chip material and processing have an essential role in the characteristics of powder particles, such as particle size, shape, size distribution and structure $\left(4 S^{\prime}\right.$ s), which are essential parameters that must be considered having in mind the powder process and the metallurgy applications. Moreover, different approaches refereed in the application of this new "powder process" are highlighted. The goal is to show how the actual research has been transforming subtractive processes from a contributor of wastes to clean technologies.
\end{abstract}

Keywords: metal chips; milling; powder characteristics; sintering; additive manufacturing

\section{Introduction}

The evolution of technology and increase in population have directed human beings to consumerism, facing exponential industrial growth with environmental impacts, such as consumption of minerals, generation of energy and production of wastes, highly seen in the steel industry. Thus, circular economy is highlighted regarding recycling or adding value to chips through the definition of new applications [1]. Hence, different studies evaluated the reuse of metal chips in various applications, e.g., the replacement of sands by metal chips in concrete production [2], the production of porous structures by sintering powders mixed with metal chips [3] or the use of steel chips as reinforcement in metal matrices [4,5]. However, the success of these applications depends on the state of interactions of chips with the matrix, e.g., the oxidation of chips in concrete may occur; the bonding between matrix and chips or between chips-chips is essential for the strength of densified product. Regarding the success of using metal chips as new resources, one study highlighted the effect of extrusion temperature and rate of extruding on the densification of product, though authors reported that the mechanical properties of the extruded product were poorer than that of the commercial material, that shortcoming was attributed to the porosity formed in the extruded chips [6].

Other application for metal chips can involve powder production by milling. This approach seems noticeable since the use of these materials appears sustainable $[7,8]$. Moreover, metal chips are available as major wastes in the machining industry and the use of 
these materials for powder production is in the scope of Goal 12 of the 2030 Agenda (Transforming our World: the 2030 Agenda for Sustainable Development). The transformation of metal chips into powders requires performing intense milling, this production consists of inducing fracture in chips by milling in conventional conditions with and without a cryogenic environment. These treatments can introduce different degrees of metastability (such as nanostructures) in the chips material by severe plastic deformation. The current study reviews the state-of-the-art methods for powder production from metal chips considering milling conditions and powder characteristics, mainly the $4 S^{\prime}$ s, such as particle size, particle size distribution, particle shape and the structure of particles, as well as the potential applications for these powders.

\section{Materials of Chips}

The metal chips used for recycling can involve industrial residues [9] or as machined fresh type [10], resulting from operations such as turning [11,12], roughing and finishing [13] obtained by low speed machining [14,15] or a high speed process [13]. Materials studied so far involve aluminum alloys, stainless steel, tool steel, titanium alloy, tin alloy and nickel alloy, with different initial sizes.

\section{Powder Production}

Milling techniques can include: (1) attritor ball milling that can be categorized as dry grinding or wet grinding, using regular speed (to $400 \mathrm{rpm}$ ) or high speed (400-1800 rpm) attritors [10,16]; (2) roll milling [17]; (3) planetary type [7,13]; (4) disc milling [10,18,19]. Powder production mostly involves fracturing cleaned and dried chips/swarf; meanwhile, cold welding between fragments may occur; however, this joining depends on the energy and conditions of milling. Chips face plastic deformation and consequently fracture. The fragmentation occurs by compaction or impaction accompanied or not with friction depending on the milling technique and procedure. Moreover, particle fragments can be associated with grain refinement, possible to reach nanocrystallinity through high energy milling [20].

Regarding mechanical milling processes, such as the planetary technique, it is important to consider the processing parameters and conditions. Milling energy is influenced by milling time and revolutions per minute (rpm), even ball to powder ratio (BPR). Other conditions, such as the milling atmosphere, the use of process control agent (PCA), and the temperature of milling, are significant too. These conditions affect the evolution of the $4 S^{\prime} s$ of the milled product [21]. Moreover, the characteristics of the milling, such as the material and size of the milling jar and that of the balls, seem to be effective; one study showed that coarser particles were the result of balls with $20 \mathrm{~mm}$ diameter than balls of $6 \mathrm{~mm}$ [22].

Though the application of cryogenic ambient during milling seems to be effective for powder fragmentation, influencing ductile to brittle fracture temperature transition, some authors reported that disc milling was more productive than ball milling or cryogenic milling/grinding system, taking into account the time of milling for transferring all chips into powders [18].

The jet milling technique was also applied for the powder production from bronze chips [23]. This technique implemented a jet flux for impacting chips on a hard target by which impaction and attrition, rather than wear, were responsible for fragmentation. The impact angle and the distance between the nozzle and target were effective parameters. It revealed that fragmentation by ball milling required larger time in comparison with jet milling by which a faster fragmentation and a greater efficiency were achieved; however, the effect of jet milling was pronounced in the first cycle attributed to the presence of cracks and defects caused by the machining process [23].

Fragmentation is greatly influenced by the type of milling process applied on chips, a higher efficiency of powder production was highlighted for the mill shaker technique than the planetary milling, achieving a faster size refinement was attributed to the milling energy induced by the shaking process [24]. Moreover, the collision energy also depends 
on the milling technique. Some authors attributed the efficiency of a high fragmentation to impact energy implemented by disc milling in comparison with cryogenic mill and ball miller [18].

In addition, the application of PCA is important; it is usually used to avoid adhesion between particles to balls or to prevent cold welding between particles in order to dominant fracturing; PCA can define the distribution size and morphology of the milled particles. Methanol and stearic acid (SA) are common PCAs. One study presented the production of a d$_{50}$ of $100 \mu \mathrm{m}$ to $325 \mu \mathrm{m}$; however, the finest particles $\left(\mathrm{d}_{50}\right.$ of $\left.\sim 140 \mu \mathrm{m}\right)$ were produced by introducing $0.5 \mathrm{wt} . \% \mathrm{SA}$ to the chips before milling [8].

Regarding the milling atmosphere, the most common is Argon gas, which is very useful to avoid oxidation of metal particles, as contaminations, during milling [20]. However, other strategies can be selected for that purpose, such as adding PCA, e.g., a toluene environment [25].

Regarding the effect of BPR, the application of more balls increases collisions with particles increasing fragmentation. Therefore, the application of a higher BPR can increase the efficiency of milling [25]. Thus, it would be interesting to evaluate the effect of BPR on fragmentation vs. the influence of milling time for future objectives as a solution for reducing energy consumption.

\section{Characterization of Powder Particles Produced from Metal Chips}

\subsection{Particle Size}

Particle size analysis determines the progress of fragmentation during mechanical milling chips for powder production. This analysis can be performed by several techniques: sieving that is reported in wt.\%, image analysis acquired by transmitting optical microscope $(\mathrm{OM})$ or stereoscopic macroscope (SM) or scanning electron microscope (SEM). Other techniques include static light scattering (SLS), laser particle size analyzer (LPSA) or laser diffraction (LD) particle size analyzer (PSA).

The evolution of particle size is governed by the fragmentation of metal chips and is dependent on the materials characteristics and processing conditions as well. Regarding the influence of material, some authors showed the production of particles in dissimilar sizes from similar milling of different chips; that difference was attributed to the primary conditions of the chips used for milling [17]. Table 1 shows the function of the material chips, the different studies performed during the last decennia concerning particle size and the milling process.

Table 1. Milling of different material chips.

\begin{tabular}{|c|c|c|c|c|c|}
\hline & Input Material & Conditions & Results & $\begin{array}{l}\text { Analysis } \\
\text { Method }\end{array}$ & Reference \\
\hline \multirow{6}{*}{ 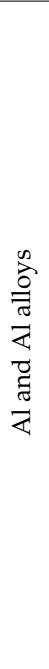 } & Aluminum in max. $6 \mathrm{~mm}$ length & $\begin{array}{c}\text { Cut milling chips to } 4-2 \mathrm{~mm} \text {, attritor } \\
\text { milling ( } 300 \mathrm{rpm}, 20 \mathrm{~mm} \varphi \text { balls BPR of } \\
10: 1) \text { in air }\end{array}$ & $<500 \mu \mathrm{m}$ & Sieved & [10] \\
\hline & $\begin{array}{l}\mathrm{AlSi}_{5} \mathrm{Cu}_{2} \text { aluminum alloy with } 250 \mu \mathrm{m} \text {, } \\
\text { heat treated }\end{array}$ & $\begin{array}{c}\text { High energy ball mil (200 rpm, BPR of } \\
\text { 10:1) in argon, with } 1 \text { wt. } \% \text { stearic acid } \\
\text { and with SiC particles }(10,20 \mathrm{wt} . \%) \\
\text { for } 40 \mathrm{~h}\end{array}$ & $3 \mu \mathrm{m}$ & SEM & [11] \\
\hline & $\begin{array}{l}\text { AA7075 }(10 \mathrm{~mm} \times 2 \mathrm{~mm} \times 0.5 \mathrm{~mm}) \\
\text { after cut by double roller }\end{array}$ & $\begin{array}{l}\text { High energy planetary ball milling (400 } \\
\text { rpm, carbide tungsten vials, BPR of } \\
30: 1 \text { ) in argon and with } 2 \% \text { methanol for } \\
0.5 \text { to } 10 \mathrm{~h}\end{array}$ & $\begin{array}{l}5 \mathrm{~h}: \mathrm{d}_{50}=75 \mu \mathrm{m} \\
10 \mathrm{~h}: \mathrm{d}_{50}=35 \mu \mathrm{m}\end{array}$ & $\begin{array}{l}\text { SEM } \\
\text { LPSA }\end{array}$ & [12] \\
\hline & AA6013-T6 in 4-10 mm & $\begin{array}{l}\text { (1) Cryogenic milling ( } 25 \mathrm{~mm} \varphi \\
\text { stainless steel ball, nitrogen cooling) } \\
\text { stages for } 24 \mathrm{~min} \\
\text { (2) Disc milling (1500 rpm) for } 4 \mathrm{~min} \\
\text { (3) Ball milling ( } 550 \mathrm{rpm}, 25 \mathrm{~mm} \varphi \\
\text { stainless steel ball) stages of } 40 \mathrm{~min}\end{array}$ & $\begin{array}{l}\text { (1) Cryogenic mill: } \\
d_{50}=88 \mu \mathrm{m} \\
\text { (2) Disc mill: } d_{50}=42 \mu \mathrm{m} \\
\text { (3) Ball mill: not } \\
\text { mentioned }\end{array}$ & LD & [18] \\
\hline & $\begin{array}{c}\text { AA2024 } \\
20 \mathrm{~mm} \times 9 \mathrm{~mm} \times 0.1 \mathrm{~mm}\end{array}$ & $\begin{array}{c}\text { Planetary ball milling ( } 300 \mathrm{rpm}, 16 \mathrm{~mm} \\
\varphi \text { stainless steel balls, BPR of 10:1) in air } \\
\text { in different regimes with and without } \\
\text { SA for } 100 \mathrm{~min}\end{array}$ & $\begin{array}{l}\mathrm{d}_{50} \text { of } \sim 140 \mu \mathrm{m} \text { by an } \\
\text { optimized regime }\end{array}$ & $\begin{array}{l}\text { SEM } \\
\text { OM } \\
\text { SLS }\end{array}$ & [8] \\
\hline & $\begin{array}{l}\text { Aluminum metal swarf with } 3 \mathrm{~mm} \\
\text { after blended }\end{array}$ & $\begin{array}{c}\text { Ball milling ( } 370 \mathrm{rpm}, 10 \mathrm{~mm} \varphi 36 \\
\text { zirconia balls) with and without PCA }\end{array}$ & $\begin{aligned} \mathrm{d}_{50}= & 34.829 \mu \mathrm{m} \text { at least } \\
& 7 \mathrm{~h} \text { of milling }\end{aligned}$ & LD & [9] \\
\hline
\end{tabular}


Table 1. Cont.

\begin{tabular}{|c|c|c|c|c|c|}
\hline & Input Material & Conditions & Results & $\begin{array}{l}\text { Analysis } \\
\text { Method }\end{array}$ & Reference \\
\hline \multirow{5}{*}{ 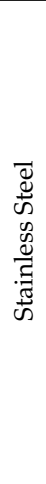 } & $\begin{array}{l}\text { Stainless steel in 2-4 mm discontinuous, } \\
\text { non-stringy and C-shape }\end{array}$ & $\begin{array}{l}\text { Planetary ball milling ( } 400 \mathrm{rpm}, 20 \mathrm{~mm} \\
\varphi \text { hardened chromium steel balls, BPR } \\
\text { of 10:1) in argon for } 25,50,100 \mathrm{~h}\end{array}$ & $\begin{array}{l}50 \mathrm{~h}: 300 \mu \mathrm{m} \\
100 \mathrm{~h}: 60 \mu \mathrm{m}\end{array}$ & SEM & [7] \\
\hline & $\begin{array}{l}\text { UNS S31803 duplex stainless steel, thin } \\
\text { and small chips short spiral type } \\
\text { machining at low speed } \\
2 \text { mm of mean size }\end{array}$ & $\begin{array}{l}\text { Planetary ball mill ( } 350 \mathrm{rpm}, 5 \text { and } 20 \mathrm{~h} \text {, } \\
\text { BPR of 15:1) in argon with and without } \\
3 \% \mathrm{NbC} \text { for } 5 \text { and } 20 \mathrm{~h}\end{array}$ & $\begin{array}{c}5 \mathrm{~h}: 600 \mu \mathrm{m} \\
20 \mathrm{~h}: 219.7 \mu \mathrm{m} \\
5 \mathrm{~h}+3 \% \mathrm{NbC}: 150-500 \mu \mathrm{m} \\
20 \mathrm{~h}+3 \% \mathrm{NbC}: 175.6 \mu \mathrm{m}\end{array}$ & $\begin{array}{l}\text { SM } \\
\text { SEM } \\
\text { PSA }\end{array}$ & [28] \\
\hline & $\begin{array}{c}\text { UNS S31803 duplex stainless steel } \\
\text { machining at low speed } \\
\text { 5-15 mm }\end{array}$ & $\begin{array}{c}\text { Planetary ball mill ( } 250-350 \mathrm{rpm}, \mathrm{BPR} \\
\text { of 20:1) in argon and } 0-3 \% \text { VC for } 10 \\
\text { to } 50 \mathrm{~h}\end{array}$ & $\begin{array}{l}25-135 \mu \mathrm{m} \text { at more } \\
\text { aggressive conditions }\end{array}$ & $\begin{array}{l}\text { SEM } \\
\text { PSA }\end{array}$ & [5] \\
\hline & $\begin{array}{c}\text { AISI 304L } \\
\text { Chips with serrations along the length } \\
5-20 \mathrm{~mm}\end{array}$ & $\begin{array}{c}\text { Planetary ball mill ( } 500 \mathrm{rpm} \\
6 \text { and } 20 \mathrm{~mm} \varphi \text { stainless steel balls, BPR } \\
\text { of 15:1) in argon }\end{array}$ & $\begin{array}{l}38-150 \mu \mathrm{m} \text { by an } \\
\text { optimized regime }\end{array}$ & Sieved & [22] \\
\hline & $\begin{array}{l}\text { Fe- } 11 \mathrm{Cr}-1.5 \mathrm{Ni}-0.2 \mathrm{~V}-0.4 \mathrm{Mo}-0.1 \mathrm{C} \\
\text { shear-localized chips with } 5-6 \mathrm{~mm} \text { in } \\
\text { length and } 1 \mathrm{~mm} \text { in thickness }\end{array}$ & $\begin{array}{c}\text { Attritor with grinding ball }(260 \mathrm{rpm} \text {, } \\
7-10 \mathrm{~mm} \varphi \text { balls, BPR of } 10: 1,40 \mathrm{~kg} \text { ball } \\
\text { charge) with } 0.2 \mathrm{wt} . \% \text { stearic acid in } \\
\text { argon for } 6-12 \mathrm{ks}\end{array}$ & $\begin{array}{l}91 \mathrm{wt} . \% \text { content of powder } \\
\text { particles }<125 \mu \mathrm{m} \\
\text { form } 12 \mathrm{ks}\end{array}$ & Sieved & [16] \\
\hline \multirow{4}{*}{$\underset{\Phi}{\Phi}$} & $\begin{array}{c}\text { Three different steel chips } 10 \mathrm{~mm} \text { across } \\
\text { and } 1.5 \mathrm{~mm} \text { thickness }\end{array}$ & $\begin{array}{l}\text { Rolling ball mill ( } 231 \mathrm{rpm}, 10 \mathrm{~mm} \varphi \\
\text { porcelain balls) for } 2 \mathrm{~h} \text { and } 6 \mathrm{~h}\end{array}$ & $6 \mathrm{~h} \geq$ finer particles & Sieved & [17] \\
\hline & $\begin{array}{c}\text { AISI H13 } \\
\text { high speed machining chips with } \\
0.1-0.5 \mathrm{~mm} \text { (finishing) and } 5-7 \mathrm{~mm} \\
\text { (roughing) }\end{array}$ & $\begin{array}{c}\text { Planetary ball mill (300 and } 450 \mathrm{rpm} \text {, } \\
20 \mathrm{~mm} \varphi \text { hardened chromium steel } \\
\text { balls, BPR of } 20: 1 \text { and } 10: 1) \text { in } \mathrm{Ar}+\mathrm{H}_{2} \\
(5 \%) \text { until } 300 \mathrm{~min}\end{array}$ & $\begin{array}{l}\mathrm{d}_{50}=53 \mu \mathrm{m} \text { at } 450 \mathrm{rpm} \\
180 \mathrm{~min} \text { BPR of } 10: 1\end{array}$ & $\stackrel{\mathrm{L}}{\mathrm{DSEM}}$ & [13] \\
\hline & $\begin{array}{l}\text { Low carbon steel and extra-low carbon } \\
\text { steel (LCS and ELCS, respectively) }\end{array}$ & $\begin{array}{l}\text { High energy dual drive planetary mill } \\
\text { (Jar:620 rpm, main shaft: } 275 \mathrm{rpm}, \\
10 \mathrm{~mm} \varphi \text { stainless steel balls, BPR of } \\
\text { 12:1 and } 6: 1 \text { ) immersed in toluene }\end{array}$ & 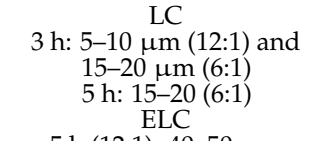 & SEM & [25] \\
\hline & $\begin{array}{l}\mathrm{Ti}_{6} \mathrm{Al}_{4} \mathrm{~V} \text { scrap chips in spring shape size } \\
\text { chips with }<2 \mathrm{~cm} \text { after crush. }\end{array}$ & $\begin{array}{c}\text { (1) Planetary milling ( } 500 \mathrm{rpm}, 20 \mathrm{~mm} \\
\varphi \text { hardened carbon } \\
\text { steel balls, BPR of 10:1) in argon for 5, } \\
\text { 10, 20, 30, 40 and } 50 \mathrm{~h} \\
\text { (2) Shaker milling (613 rpm, } 4 \mathrm{~mm} \varphi \\
\text { hardened carbon } \\
\text { steel balls, BPR of 10:1) in Argon for 1, 2, } \\
\quad 8 \text { and } 10 \mathrm{~h} \text {. }\end{array}$ & $\begin{array}{c}5 \mathrm{~h}(12: 1): 40-50 \mu \mathrm{m} \\
\text { (1) Planetary mil: } \\
5 \mathrm{~h}:<600 \mu \mathrm{m} \\
10 \mathrm{~h}:<400 \mu \mathrm{m} \\
20 \mathrm{~h}: \sim 300 \mu \mathrm{m} \\
30 \mathrm{~h}: \sim 300 \mu \mathrm{m} \\
40 \mathrm{~h}: \sim 200 \mu \mathrm{m} \\
50 \mathrm{~h}:<100 \mu \mathrm{m} \\
\text { (2) Shaker milling } \\
1 \mathrm{~h}: \sim 800 \mu \mathrm{m} \\
2 \mathrm{~h}:<700 \mu \mathrm{m} \\
8 \mathrm{~h}:<400 \mu \mathrm{m} \\
10 \mathrm{~h}:<50 \mu \mathrm{m}\end{array}$ & SEM & [24] \\
\hline \multirow{6}{*}{ 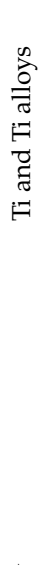 } & $\begin{array}{c}\mathrm{Ti}_{6} \mathrm{Al}_{4} \mathrm{~V} \text { machining chips in } \\
\text { spring shape }\end{array}$ & $\begin{array}{c}\text { Planetary ball mill (500 rpm, } 20 \mathrm{~mm} \varphi \\
\text { hardened carbon steel balls, BPR of 10:1) } \\
\text { in argon for } 5,10,20,30,40 \text { and } 50 \mathrm{~h} \\
\text { with and without } 10 \mathrm{wt} . \% \\
\mathrm{Al}_{2} \mathrm{O}_{3} \text { nanoparticles }\end{array}$ & $\begin{array}{c}50 \mathrm{~h}:<80 \mu \mathrm{m} \\
\text { With } \mathrm{Al}_{2} \mathrm{O}_{3}: \\
20 \mathrm{~h}: \sim 225 \mu \mathrm{m} \\
30 \mathrm{~h}: \sim 6 \mu \mathrm{m} \\
50 \mathrm{~h}: \sim 4 \mu \mathrm{m}\end{array}$ & SEM & [27] \\
\hline & $\begin{array}{c}\mathrm{Ti}_{6} \mathrm{Al}_{4} \mathrm{~V} \text { spiral machining chips, heat } \\
\text { treated at different temperatures } \\
\text { in } \mathrm{H}_{2}-\mathrm{Ar}\end{array}$ & $\begin{array}{l}\text { Planetary ball milling (200 rpm, BPR of } \\
\text { 12:1, } 10 \mathrm{~mm} \varphi \mathrm{ZrO}_{2} \text { balls) for 10, 30, } \\
60 \mathrm{~min}\end{array}$ & $\begin{array}{c}\mathrm{d}_{50}=120 \mu \mathrm{m} \text { obtained by } \\
60 \text { min milling of chips } \\
\text { heat treated at } 800^{\circ} \mathrm{C} \text { for } \\
30 \mathrm{~min}\end{array}$ & LD & [26] \\
\hline & $\begin{array}{l}\mathrm{Ti}_{6} \mathrm{Al}_{4} \mathrm{~V} \text { machining scraps in } \\
\text { spring-like shape }\end{array}$ & $\begin{array}{l}\text { Disc milling (800 to } 1400 \mathrm{rpm} \text { ) in air } \\
\text { atmosphere for } 4,8,12,16,20 \text { and } \\
24 \mathrm{~min}\end{array}$ & $\begin{array}{c}\mathrm{d}_{50}=211 \mu \mathrm{m} \text { at } 1200 \mathrm{rpm} \\
\text { for } 24 \mathrm{~min}\end{array}$ & $\begin{array}{l}\text { SEM } \\
\text { PSA }\end{array}$ & [29] \\
\hline & $\mathrm{Ti}_{6} \mathrm{Al}_{4} \mathrm{~V}$ & $\begin{array}{l}\text { High energy planetary ball mill for } 3 \mathrm{~h} \\
\text { Dual drive planetary mill (jar: } 620 \mathrm{rpm} \text {, }\end{array}$ & $\leq 50 \mu \mathrm{m}$ & - & [30] \\
\hline & $\begin{array}{l}\text { Ti spring shape chips with } 8-10 \mathrm{~mm} \\
\text { after cutting }\end{array}$ & $\begin{array}{c}\text { main shaft: } 275 \mathrm{rpm}, 8 \mathrm{~mm} \varphi \text { stainless } \\
\text { balls, BPR of 10:1) immersed under } \\
\text { toluene for } 2.5 \mathrm{~h}\end{array}$ & $5-10 \mu \mathrm{m}$ & $\begin{array}{l}\text { SEM } \\
\text { FESEM }\end{array}$ & {$[31]$} \\
\hline & $\begin{array}{l}\mathrm{Ti}_{6} \mathrm{Al}_{4} \mathrm{~V} \\
2000 \mu \mathrm{m}\end{array}$ & $\begin{array}{l}\text { Vibratory disc mill }(700,800,900 \text {, and } \\
1000 \mathrm{r} / \mathrm{min} \text { at different sieving sizes } \\
2000,500,300 \text { and } 200 \mu \mathrm{m})\end{array}$ & $40-212 \mu \mathrm{m}$ & Sieving & [32] \\
\hline 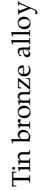 & $\begin{array}{l}\text { Tin bronze alloy } \\
595-841 \mu \mathrm{m}\end{array}$ & $\begin{array}{c}\text { (1) Ball mill (60 rpm, tool steel balls, } \\
\text { BPR of 20:1) in air for } 4,8,16 \text { and } 24 \mathrm{~h} \\
\text { (2) Target jet mill (nozzle to target } \\
\text { distance: } 8 \mathrm{~cm} \text {, impact angle: } 90^{\circ} \\
\text { compressed air: } 6 \text { bar) for } 1,3,5,7 \\
\text { and } 10 \mathrm{~h}\end{array}$ & $\begin{array}{l}\text { (1) Ball mill: } \\
24 \text { h: } 308 \mu \mathrm{m} \\
\text { (2) Target jet mill: } 10 \mathrm{~h}: \\
181 \mu \mathrm{m}\end{array}$ & $\begin{array}{l}\text { SEM } \\
\text { Sieving }\end{array}$ & [23] \\
\hline 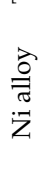 & $\begin{array}{l}\text { Alloy metal with } 77 \% \text { Ni chips } \\
\text { Crusher in a hammer mill to }<2.5 \mathrm{~mm}\end{array}$ & $\begin{array}{l}\text { (1) Eight-chamber continuous-discharge } \\
\text { vibration roller mill }(\mathrm{f}=19.5 \mathrm{~Hz} \text { and } \\
\mathrm{A}=6.7 \mathrm{~mm}) \text { in four stages } \\
\text { (2) Batch-operated cantilever-type ball } \\
\text { mill }(71 \mathrm{rpm}, 40,25 \text { and } 20 \mathrm{~mm} \varphi \text { balls } \\
\text { with ratio } 50: 34: 16,87.5 \mathrm{~h})\end{array}$ & $\begin{array}{l}\text { (1) Vibration mill: } 51.5 \% \text { of } \\
\text { particles }<125 \mu \mathrm{m} \text {; } \\
\text { (2) Ball mill: } 63.1 \% \text { of } \\
\text { particles }<125 \mu \mathrm{m} \text {. }\end{array}$ & Sieving PSA & [33] \\
\hline
\end{tabular}

Some authors revealed the success of applying a pre-heat treatment on a Ti alloy, heating in an $\mathrm{H}_{2}$-Ar mixture atmosphere, on decreasing particle size, the production of fine particles was attributed to the formation of brittle $\mathrm{TiH}_{2}$ compound during the pre- 
heat treatment step [26]. Another study evaluated the effect of chemical composition on fragmentation, the application of similar milling conditions on two steels, an extra low carbon steel and a low carbon type, the former type faced with agglomeration formation caused by cold welding. Moreover, same authors revealed that the larger the BPR ratio, the finer the particle size.

Regarding the achievement of smaller particle size, some studies performed showing that the fragmentation can increase in the presence of a harder phase mixed with the matrix during milling; some authors proved this concept by milling $\mathrm{Ti}_{6} \mathrm{Al}_{4} \mathrm{~V}$ chips mixed with $10 \mathrm{wt} . \%$ of alumina particles, showing a sharp reduction of particle size [27].

Milling time also influences fragmentation and particle size formation, e.g., an increase from $3 \mathrm{~h}$ to $5 \mathrm{~h}$ milling increased yield fragmentation [25]. Fragmentation continues by prolonging milling time though agglomeration of fine particles and formation of clusters can appear, e.g., particles of $\sim 1 \mu \mathrm{m}$, in clusters, formed within $50 \mathrm{~h}$ ball milling of $\mathrm{Ti}_{6} \mathrm{Al}_{4} \mathrm{~V}$ particles [24]. Figure 1 illustrates the particle size of recycled powders in different alloys influenced by processing methodology and conditions.

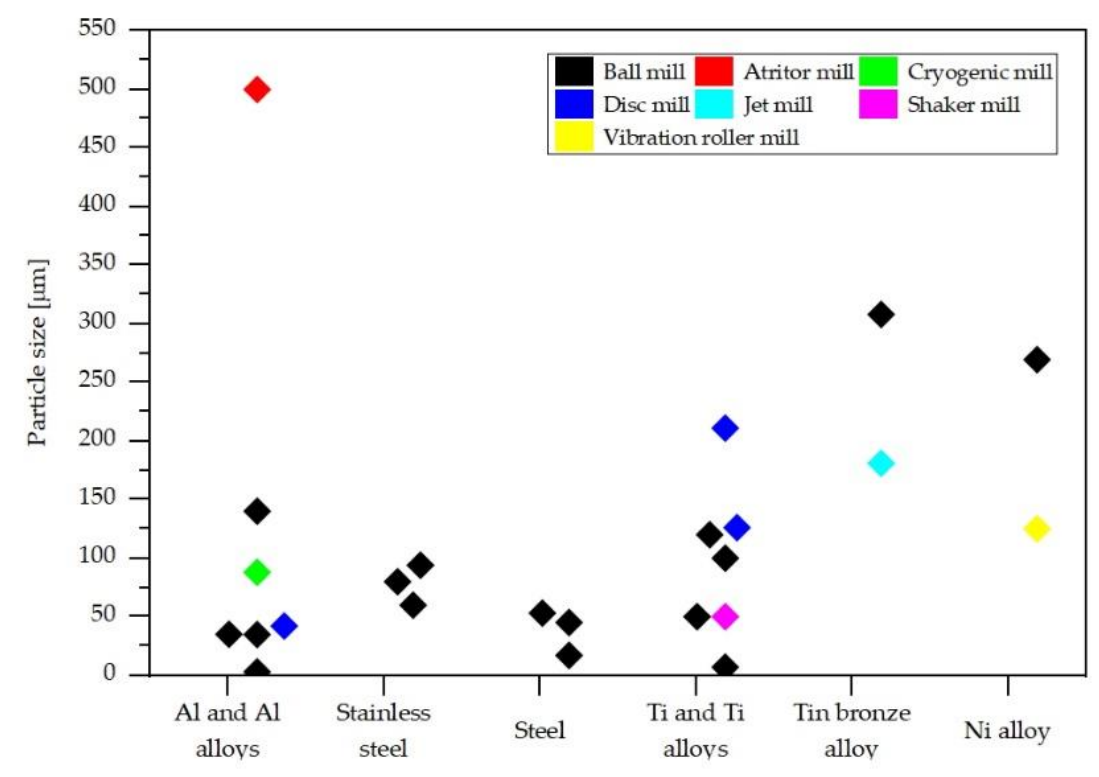

Figure 1. Illustration of particle size mentioned in Table 1.

\subsection{Particle Size Distribution}

The particle size distribution (PSD) can be affected by the presence of additives, such as PCA and even reinforcements (e.g., niobium carbide ( $\mathrm{NbC}$ ), vanadium carbide (VC), silicon carbide ( $\mathrm{SiC}$ ) or Titanium carbide ( $\mathrm{TiC})$ ), milling time or by the technique chosen for milling. Regarding the use of SA as a PCA, the procedure of addition is very important. Table 2 shows the function of the material chips and the different studies performed during the last decennia concerning particle size distribution function of milling conditions (Table 1). Some authors revealed the production of finer particles, $d_{50}$ of almost $100 \mu \mathrm{m}$, by the addition of SA in the beginning of the milling process [8]. As regards the fragmentation in the presence of reinforcement, an addition of a $3 \% \mathrm{NbC}$ resulted in narrowing particle size distribution [28].

Table 2. Particle size distribution.

\begin{tabular}{cccc}
\hline Input Material & Particle Size Distribution & Analysis Method & Reference \\
\hline AA2024 & $\mathrm{d}_{50}=100-325 \mu \mathrm{m}$ & SLS and SEM & [8] \\
Stainless steel & Reported as narrow size distribution & SEM & [7] \\
UNS S31803 duplex stainless steel & Without NbC: $\mathrm{d}_{10}=65.3, \mathrm{~d}_{50}=134.8 \mathrm{~d}_{90}=473.3$ & SEM and PSA & [28] \\
& With $3 \% \mathrm{NbC}: \mathrm{d}_{10}=65.6, \mathrm{~d}_{50}=115.8, \mathrm{~d}_{90}=355.7$ & & \\
\hline
\end{tabular}


A comparative study between jet milling and ball milling revealed a larger peak broadening for the PSD of particles obtained by ball milling attributed to the hardening of particles that occurred during the ball milling process [23].

\subsection{Particle Shape}

Table 3 and Figure 2 summarize the different research works about the particle shape function of material and the milling process (Table 1). The morphology of the milled particles is strongly influenced by the milling time, i.e., during the initial steps a flake-like shape is obtained, this shape changes to spherical particles by prolonging milling time by which particles are repeatedly cold welded and fractured [24]. Some authors reported the production of $\mathrm{H} 13$ particles with metallic appearance of an aspect ratio close to one by prolonging milling time [13].

Table 3. Particle shape.

\begin{tabular}{|c|c|c|c|}
\hline Input Material & Particle Shape & Analysis Method & Reference \\
\hline AA7075 & $\begin{array}{l}5 \mathrm{~h} \text { milling is the critical time for morphology change, } \\
\text { chips with segmented shape to irregular powder } \\
\text { morphology }\end{array}$ & SEM & [12] \\
\hline AA6013 & $\begin{array}{l}\text { Flaky and irregular shaped. Average aspect ratio of } 1.25 \\
\text { (disc mill), } 1.42 \text { (cryogenic mill) and } 1.63 \text { (ball mill) }\end{array}$ & $\mathrm{OM}$ & [18] \\
\hline AA2024 & Flake shaped & SEM & [8] \\
\hline Stainless steel & Spherical powders & SEM & [7] \\
\hline AISI 304L & $\begin{array}{l}\text { Rounded particles and smoother surfaces with average } \\
\text { aspect ratio of } 1.37\end{array}$ & SEM & [22] \\
\hline Fe-11Cr-1.5Ni-0.2V-0.4Mo-0.1C & $\begin{array}{l}\text { Flake shape after milling and spherical }(>85 \%) \text { or rather } \\
\text { spherical shaped particles after plasma spheroidization } \\
\text { applying a feeding rate of } 30 \mathrm{~g} / \mathrm{min}\end{array}$ & Tomography & [16] \\
\hline Three different steel chips & Flake shape & - & [17] \\
\hline & $\begin{array}{l}\text { Planetary ball mill: } \\
5 \text { h: Flake shape }\end{array}$ & & \\
\hline $\mathrm{Ti}_{6} \mathrm{Al}_{4} \mathrm{~V}$ & $\begin{array}{c}10<\mathrm{h}<50: \text { spherical } \\
\text { Shaker ball mill: } \\
2 \mathrm{~h}: \text { flake-like } \\
10 \mathrm{~h} \text { : angular }\end{array}$ & SEM & [24] \\
\hline & 5 h: Flake shape & & \\
\hline & $\begin{array}{l}10 \text { h: Equiaxed shaped particles } \\
20 \text { h: Large cluster (agglomerated particles) }\end{array}$ & & \\
\hline $\mathrm{Ti}_{6} \mathrm{Al}_{4} \mathrm{~V}$ & $\begin{array}{c}\text { 30-50 h: decrease in clusters } \\
\text { With } 10 \text { wt. } \% \mathrm{Al}_{2} \mathrm{O}_{3}: \\
2 \mathrm{~h}: \text { Flake shape } \\
10 \text { h: Equiaxed in shape } \\
20 \mathrm{~h}: \text { Smaller particles }\end{array}$ & SEM & {$[27]$} \\
\hline $\mathrm{Ti}_{6} \mathrm{Al}_{4} \mathrm{~V}$ & Spring-like scraps turn into flaky powder form & SEM & [29] \\
\hline Tin bronze alloy & $\begin{array}{l}\text { Jet milling powder: irregular shape } \\
\text { Ball milling powder: rounded with smooth surface }\end{array}$ & SEM & [23] \\
\hline
\end{tabular}

Moreover, the powder shape is influenced by the milling technique, the production of angular and agglomerate-free particles was remarked by the performance of shaker milling that was independent on milling time [24]. The diameter of the balls used in mechanical milling also has an influence on the morphology of the powder particles. Applying a similar BPR, large balls (diameter $=20 \mathrm{~mm}$ ) efficiently break up chips to coarse powder particles while small balls (diameter $=6 \mathrm{~mm}$ ) effectively modify the powder morphology to nearspherical [22]. Some authors highlighted the effectiveness of ball size on the morphology of milled particles, i.e., a two-stage ball milling starting by large balls and ended with small balls, $\varphi=6 \mathrm{~mm}$ and $20 \mathrm{~mm}$, resulted in the production of near-spherical particles [22,34]. 


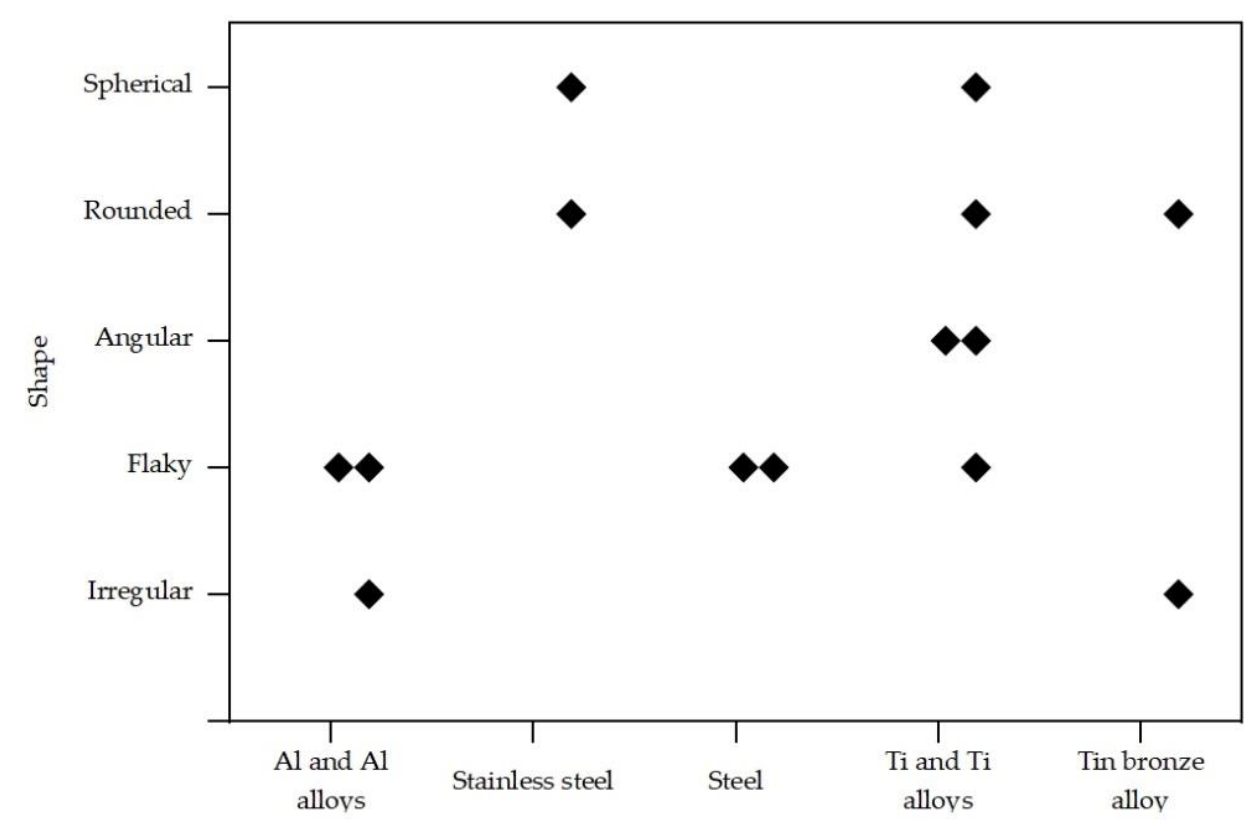

Figure 2. Illustration of particle shape mentioned in Table 3 (diamond inserts in this graph represent studies discussed in this review article, as cited in Table 3).

In addition, other authors showed that the use of PCA, such as SA, influenced the particle shape, depending on the milling time in the presence of SA [8].

Regarding particle shape applied in powder metallurgy, ISO 3252:2019 provides complete information, defining acicular particles to spheroidal type, defined by microscopic observations. However, microscopic images can be evaluated quantitatively, defining aspect ratio (proportion of the longest diameter to the shortest aspect of one particle). Nonetheless, a recent study applied the plasma spheroidization technique on milled particles in order to accomplish the aspect ratio of one so that spherical shaped particles could be achieved; however, the shape factor was dependent on the powder feeding rate during the spheroidization process [16].

\subsection{Particle Structure}

Table 4 shows the structure of milled chips for different materials. Some researchers illustrated the presence of sub-micrometric to nanometric grain sizes as well as a martensitic structure H13, (AISI) tool steel, chips produced by a machining process in air [35]. A recent study based on SEM, X-ray diffraction (XRD), Transmission Electron Microscopy (TEM) and Electron Backscatter Diffraction (EBSD) obtained by TEM (t-EBSD), revealed that the microstructure inside the adiabatic shear band, consisting of severe deformation, is composed of ultrafine and nanocrystalline grains, adjacent areas included thin martensite laths with high dislocation density and nanocrystalline grains as well [36]. The target was to highlight the effectiveness of milling metal chips for powder production. Nevertheless, the creation of nanostructured powders was also desired. Some authors also reported the production of nanometric martensitic grains through the introduction of extremely high strain rate into austenitic stainless steel chips [7]. Moreover, other researchers showed that the application of shaker milling, that is a higher energetic process than ball milling, revealed a faster rate to achieve nanocrystallinity $-10 \mathrm{~h}$ of shaking was equivalent to $40 \mathrm{~h}$ of mill in a planetary milling [24]. Some authors mentioned the effectiveness of milling speed on attaining particle size, a non-uniform particle size distribution $(211 \mu \mathrm{m}$ produced at $1200 \mathrm{rpm}$ for $24 \mathrm{~min}$ ) without any change in the structure, the crystallite size decreased by an increase in milling speed and not milling time [29]. Considering the milling time, some authors attributed the increase in grain size to the heat effect caused by long milling time [8]. Nonetheless, the crystallite analyses in these studies were performed by X-ray 
diffraction (XRD), considering the width of peaks, EBSD or TEM. Magnetic analysis can confirm if austenite microstructure has transformed into martensite; some authors showed that annealing at $700{ }^{\circ} \mathrm{C}$, for $1 \mathrm{~h}$, reduced the strain but the microstructure still remained with a significant proportion of martensite [7]. Regarding the influence of the milling process, for instance in TiAlV alloy, some authors showed that the peak broadening in XRD was higher in powders resulting from shaker milling than ball milling [24].

Table 4. Structure of milled particles.

\begin{tabular}{|c|c|c|c|}
\hline Input Material & Initial Structure & Final Structure & Reference \\
\hline AlSi5Cu2 & - & $\begin{array}{c}\text { Elongated subgrains in } 1 \mu \mathrm{m} \text { length } \\
\text { (without } \mathrm{SiC} \text { ), spherical subgrains of } \\
\text { size below } 50 \mathrm{~nm}(20 \mathrm{wt} \% \mathrm{SiC} \text { after } \\
40 \mathrm{~h} \text { milling) }\end{array}$ & [11] \\
\hline AA2024 & Nanocrystalline structure $(\sim 10 \mathrm{~nm})$ & Nanocrystalline structure $(25-45 \mathrm{~nm})$ & [8] \\
\hline Stainless steel & Austenite + martensite & $\begin{array}{c}\text { Martensite is dominant after } \\
25 \mathrm{~h} \text { milling }\end{array}$ & {$[7]$} \\
\hline $\begin{array}{l}\text { UNS S31803 duplex } \\
\text { stainless steel }\end{array}$ & Ferrite + austenite & 0 & {$[28]$} \\
\hline AISI $304 \mathrm{~L}$ & Austenite + martensite & $\begin{array}{l}\text { Transformation of primary austenitic } \\
\text { phase into martensitic one }\end{array}$ & {$[22]$} \\
\hline AISI H13 & $\begin{array}{l}\text { bcc martensitic phase with a fine } \\
\text { dispersion } \\
\text { of } \mathrm{V}_{\mathrm{x}} \mathrm{C}_{\mathrm{y}} \\
\text { Ultrafine and nanocrystalline grains } \\
\qquad(\bar{d}=85 \mathrm{~nm})\end{array}$ & $\mathrm{r}-\mathrm{cos}$ & [36] \\
\hline $\begin{array}{l}\text { Low carbon steel and } \\
\text { extra-low carbon steel }\end{array}$ & - & Grain size of $10-20 \mathrm{~nm}$ & {$[25]$} \\
\hline $\mathrm{Ti}_{6} \mathrm{Al}_{4} \mathrm{~V}$ & Crystallite size of $90 \mathrm{~nm}$ & $\begin{array}{l}\mathrm{Ti}_{6} \mathrm{Al}_{4} \mathrm{~V} \text { and } \mathrm{Ti}_{6} \mathrm{Al}_{4} \mathrm{~V}+\mathrm{Al}_{2} \mathrm{O}_{3} \text { with } \\
\text { crystallite sizes of } 20-15 \mathrm{~nm}\end{array}$ & [27] \\
\hline $\mathrm{Ti}$ & - & Grain size of $10-20 \mathrm{~nm}$ & [31] \\
\hline
\end{tabular}

The efficiency of shake or jet millings can exceed ball milling due to a higher energy inherent to the technique. Moreover, disc milling shows a similar trend. Regarding milling conditions, an increase in milling time leads rise yield fragmentation. However, agglomeration of fine particles and formation of clusters can happen, caused by a cold welding effect. Similar behavior can be achieved by the application of the highest ball number. In what concerns temperature, a cryogenic ambient during milling also means high powder fragmentation for materials that promote a ductile to brittle fracture. The use of controlling agents such as stearic acid or toluene also influences the fragmentation. The use of a controlled atmosphere such as argon can avoid oxidation and contamination of milled particles. Moreover, the presence of additives or milling time affect powder characteristics, in particular particle size distribution. Regarding particle shape, the diameter of the balls appears to have the strongest effect on reaching near spherical powder particles. Moreover, an increment in milling time leads to a modification of shape factor to high values. Nevertheless, shaker milling lets angular shapes and non-agglomerate structures, independently of time. Concerning particle structure, shaker milling reveals a fast rate to achieve nanocrystallinity over planetary milling. However, crystallite size can decrease by increasing the milling speed and not milling time. The presence of a hard phase mixed with the matrix as reinforcement increases the chips fragmentation, promoting particle size reduction. Moreover, the addition of hard reinforcement encourages the reduction of powder crystallite size. The phase transformation from austenite to martensite phase can occur, particularly in austenitic stainless steel, due to intensive plastic deformation.

\section{Recycling Chips for Powder Metallurgy Applications}

The recycled powder particles obtained from metal chips recovery are noteworthy for powder metallurgy applications, conventional and advanced processes, such as pressing 
and sintering, hot isostatic pressing (HIP) or additive manufacturing (AM), respectively, including direct energy deposition (DED) or selective laser melting (SLM) Table 5 shows the densification processes applied on powder milled from different materials.

Table 5. Applications of milled particles.

\begin{tabular}{|c|c|c|c|}
\hline Powder from Chips & Reinforcement & Densification Process & Reference \\
\hline Aluminum & - & Pressing & [10] \\
\hline $\mathrm{AlSi}_{5} \mathrm{Cu}_{2}$ & $\mathrm{SiC}$ & Nanostructured composite powders & [11] \\
\hline AA2024 & - & Hot-pressing & [8] \\
\hline UNS S31803 duplex stainless steel & $\mathrm{NbC}$ & - & [28] \\
\hline UNS S31803 duplex stainless steel & $\mathrm{VC}$ & $\begin{array}{l}\text { Metal-carbide composites } \\
\text { Metal-carbide composite }\end{array}$ & [15] \\
\hline UNS S31803 duplex stainless steel & VC & $\begin{array}{l}\text { Heat treatment followed by isostatic } \\
\text { pressing }\end{array}$ & [37] \\
\hline AISI 304 & - & Additive manufacturing-DED & [22] \\
\hline Fe-11Cr-1.5Ni-0.2V-0.4Mo-0.1C & - & Additive Manufacturing-SLM \& DED & [16] \\
\hline Low and extra-low carbon steel & Nanoyttria & Pressing and sintering & [25] \\
\hline $\mathrm{Ti}_{6} \mathrm{Al}_{4} \mathrm{~V}$ & 10 wt. $\% \mathrm{Al}_{2} \mathrm{O}_{3}$ & Nanocomposite powder & [27] \\
\hline $\mathrm{Ti}_{6} \mathrm{Al}_{4} \mathrm{~V}$ & - & Pressing and sinter-HIP & [26] \\
\hline $\mathrm{Ti}_{6} \mathrm{Al}_{4} \mathrm{~V}$ & - & Pressing and sinter-HIP & [32] \\
\hline $\mathrm{Ti}$ & Graphite & $\begin{array}{c}\text { TiC reinforced Ti-TiC composite } \\
\text { powder }\end{array}$ & [31] \\
\hline Tin bronze alloy & - & Pressing & [23] \\
\hline
\end{tabular}

Some researchers studied compacted disks of $\mathrm{Al}$ powder using recycled chips, chemically cleaned prior to milling to reduce oxide on surfaces, attaining a green density of $80 \%$; these authors attributed the lack of strength of sintered powders to the weak densification [10]. Other study applied hot isostatic pressing (HIP) to increase the density of compacted and sintered $\mathrm{Ti}_{6} \mathrm{Al}_{4} \mathrm{~V}$ powder, but the densification of commercial powders was still higher than powders produced by milling [32]. With regards to the densification of recycled powders through conventional techniques, some authors suggested the production of porous bearings or even high-density $\mathrm{P} / \mathrm{M}$ structural components, using recycled tin bronze powder [23].

Metal chips were applied also for producing metal matrix powder composites. Taking into account the milling time, increase in particle size by extending milling time caused by cold welding, some authors overcame that shortcoming in the production of a duplex stainless steel composite powder mixed with vanadium carbide (VC) particles [15]. This study also presented that: the increase in the reinforcement concentration results in the reduction of average particle size. However, a similar study shows that the hardness of the sintered composite was smaller than the as-received alloy, and the failure was attributed to the porosity of sintered composite [37]. Other researchers also exhibited a significant effect on the fragmentation of particles in the presence of reinforcements, $d=80 \mu \mathrm{m}$ in $\mathrm{Ti}_{6} \mathrm{Al}_{4} \mathrm{~V}$ powder and $4 \mu \mathrm{m}$ in $\mathrm{Ti}_{6} \mathrm{Al}_{4} \mathrm{~V}-10 \mathrm{wt} . \%$ nanoalumina [27]. The same study revealed a great reduction in the crystallite size of nanocomposite powder in comparison with nonreinforced, respectively, $15 \mathrm{~nm}$ and $90 \mathrm{~nm}$. The hardness of the nanocomposite increased $168 \%$. Thus, grain coarsening did not occur in the annealed nanocomposite powders, at $600{ }^{\circ} \mathrm{C}$ for $1 \mathrm{~h}$, whereas the milled-annealed $\mathrm{Ti}_{6} \mathrm{Al}_{4} \mathrm{~V}$ powders showed significant grain coarsening [27]. Other researchers evaluated the recycling of a duplex stainless steel in the presence of $3 \%$ of $\mathrm{NbC}$ by milling, the transformation of austenite to martensite occurred, induced by severe plastic deformation though that transformation reduced in the presence of $\mathrm{NbC}$ [28]. Some researchers produced in situ TiC reinforced Ti composite powder by adding graphite to Ti chips; these authors showed that the graphite behaved as an inhibitor for fragmentation as well as oxidation [31].

Additive manufacturing, despite the high costs involved, has been acquiring significant importance due to its sustainability and the reduction of waste [34], obtained by 
skipping subtractive machining processes to achieve the final product. Other advantages from this technique are the possibility to make complex geometries, high production and low cost of transport and storage. In this process, mechanical milling is an alternative for gas atomization (GA) [34], the most common technique to produce powder with a shape factor close to 1 and controlled particle size distribution. GA is not the best option since it consumes a lot of energy, resulting in high costs and limited alloys composition for production by atomization $[34,38]$. Thus, powders for AM should have appropriate $4 S^{\prime}$ s, depending on technique, e.g., $\mathrm{d}_{90}$ of $40-140 \mu \mathrm{m}$ for direct laser deposition (DLD) or $d_{90}$ of $20-50 \mu \mathrm{m}$ for selective laser melting (SLM) and $d_{90}$ of $10 \mu \mathrm{m}$ for fused filament fabrication (FFF) $[39,40]$. Some authors developed an optimized procedure to produce powders appropriate for AM, a two-stage milling approach, i.e., balls with a diameter of $20 \mathrm{~mm}$ were used to fracture the steel chips and then balls with a diameter of $6 \mathrm{~mm}$ allowed the powder to acquire a shape factor close to 1 with a smoother surface feature. Moreover, as the milling time increased, less flattened are the particles [22]. However, a recent study performed atomization of milled particles to produce spherical shaped powders suitable for AM processing, such as DED and SLM technologies, reaching relative densities of $99 \%$ [16].

\section{Mechanical Properties}

The ball milling can induce plastic deformation as well as accumulation of internal strain, leading to the grain refinement of powder structures. This effect can induce strengthening, e.g., some authors reported the increase in hardness $(850 \mathrm{HV})$ for stainless steel recycled powder ( $100 \mathrm{~h}$ of milling), the initial chips a hardness of $374 \mathrm{HV}$. This influence is attributed to the formation of a nanosized martensite phase [7]. A similar trend was observed in other metals, affected by milling time as well $[8,9,11,22-24,32]$.

Regarding the mechanical properties of materials after densification, Table 6 revealed that mechanical properties, such as hardness or strength, depend on material composition and processing, appearing additive manufacturing is more promising.

Table 6. Mechanical properties after application of milled particles.

\begin{tabular}{|c|c|c|c|c|}
\hline Material & Densification Methodology & Analysis & Results & Reference \\
\hline Aluminium & Pressing & $\begin{array}{l}\text { Compressive strength } \\
\text { Brinel hardness }\end{array}$ & $\begin{array}{c}\text { Green compacted with commercial } \\
\text { powders had higher compressive } \\
\text { strength }(138 \mathrm{MPa}) \text { than powders from } \\
\text { chips }(120 \text { and } 135 \mathrm{MPa}) \\
\text { Hardness of commercial powders } \\
\text { (28 } \mathrm{BHN}) \text { higher than powders from } \\
\text { chips }(20 \text { and } 23 \mathrm{MPa})\end{array}$ & [10] \\
\hline AA2024 & Hot-pressing & Microhardness & $\begin{array}{c}\text { Hardness of as-compacted material } \\
\text { close to bulk alloy }(108 \mathrm{HV})\end{array}$ & [8] \\
\hline $\begin{array}{l}\text { UNS S31803-VC } \\
\text { composite }\end{array}$ & Isostatic Pressing & Microhardness & Decrease in hardness for $13 \%$ less & {$[37]$} \\
\hline AISI 304 & Additive manufacturing-DED & Nanoindentation & $\begin{array}{c}\text { Single track of powder from ball } \\
\text { milling had } 21 \% \text { more hardness than } \\
\text { single track of powder by gas } \\
\text { atomization }\end{array}$ & [22] \\
\hline $\begin{array}{l}\text { Fe-11Cr-1.5Ni-0.2V- } \\
\quad 0.4 \mathrm{Mo}-0.1 \mathrm{C}\end{array}$ & Additive Manufacturing-SLM \& DED & $\begin{array}{l}\text { Tensile strength } \\
\text { Yield point } \\
\text { Elongation }\end{array}$ & $\begin{array}{c}\text { Tensile strength and yield point above } \\
\text { standard requirements and small } \\
\text { elongation with and without heat } \\
\text { treating }\end{array}$ & [16] \\
\hline $\begin{array}{l}\text { Low and extra-low } \\
\text { carbon steel }\end{array}$ & Pressing and sintering & Microhardness & $\begin{array}{c}\text { Higher hardness in sintered powder } \\
\text { with the addition of nanoyttria (LCS: } \\
140.8 \mathrm{HV} \text { and ELCS: } 87.1 \mathrm{HV})\end{array}$ & [25] \\
\hline $\mathrm{Ti}_{6} \mathrm{Al}_{4} \mathrm{~V}$ & Pressing and sintering followed by HIP & Flexural strength & $\begin{array}{c}\text { Sintered compacts with commercial } \\
\text { powder had higher strength } \\
(\sim 450 \mathrm{MPa}) \text { then powder from chips } \\
(\sim 370 \mathrm{MPa})\end{array}$ & [32] \\
\hline Tin bronze alloy & Pressing & Green strength & $\begin{array}{l}\text { Powder from jet milling }(\sim 12 \mathrm{MPa}) \text { had } \\
\text { higher strength then powder from ball } \\
\text { milling }(\sim 5 \mathrm{MPa}) .\end{array}$ & [23] \\
\hline
\end{tabular}


The reduction in mechanical properties, such as strength and hardness, of recycled powders is attributed to efficiency of densification $[8,10,23,32]$.

\section{Conclusions and Future Perspectives}

From machining work parts is feasible for a significant number of metallic material chips (aluminum alloys, carbon steels, stainless steels, tool steels, Ti-Al alloys, superalloys) to produce powder through milling techniques. In general, these new "raw materials" take the advantage of severe plastic deformation to proceed with the fragmentation of chips. Moreover, the addition of other materials (i.e., nanoceramics) could also promote the fragmentation of ductile metallic alloys.

Depending on the pristine material, powder milling of chips have a main role in the final powder characteristics $\left(4 \mathrm{~S}^{\prime} \mathrm{s}\right)$. The new powder particles resulting from the milling of metallic chips can be applied mainly to powder metallurgy technology approaches, from conventional processes (subtractive and replicative) to additive manufacturing. This review highlights the role of metallic chips in manufacturing, and it enhances that the production of wastes is not a prerogative of subtractive process, it could be essential to additive manufacturing to guarantee its sustainability.

Regarding future perspectives, it can involve the transformation of chips in outstanding powder raw material with characteristics not available in atomized powder particles. This target will be attained by a detailed study of microstructures function of waste material and processing, milling conditions and the nanoreinforced additions. Particular attention will be dedicated to the technologies selected for 3D object production.

Author Contributions: Conceptualization, methodology, review and editing, O.E.; conceptualization, review, supervision, funding acquisition, M.T.F.V.; writing—original draft, resources, A.A.M.d.N.d.P.F.; writing, editing, resources, C.D.B. All authors have read and agreed to the published version of the manuscript.

Funding: FEDER—COMPETE, Programa Operacional Factores de Competividade, Add.Powder (39910) and by national funds provided by Fundação para a Ciência e a Tecnologia (FCT) and Centro2020 through the following Projects: UIDB/00285/2020, UIDB/04044/2020, UIDP/04044/2020 and PAMI-ROTEIRO/0328/2013 (No 022158).

Institutional Review Board Statement: Not applicable.

Informed Consent Statement: Not applicable.

Data Availability Statement: Data sharing is not applicable to this article.

Conflicts of Interest: The authors declare no conflict of interest.

\section{References}

1. Pinto, J.T.M.; Diemer, A. Supply chain integration strategies and circularity in the European steel industry. Resour. Conserv. Recycl. 2020, 153, 104517. [CrossRef]

2. Alwaeli, M.; Nadziakiewicz, J. Recycling of scale and steel chips waste as a partial replacement of sand in concrete. Constr. Build. Mater. 2012, 28, 157-163. [CrossRef]

3. Yao, B.B.; Zhou, Z.Y.; Duan, L.Y.; Xiao, Z.Y. Compressibility of 304 Stainless Steel Powder Metallurgy Materials Reinforced with 304 Short Stainless Steel Fibers. Materials 2016, 9, 161. [CrossRef] [PubMed]

4. Alaneme, K.K.; Odoni, B.U. Mechanical properties, wear and corrosion behavior of copper matrix composites reinforced with steel machining chips. Eng. Sci. Technol. Int. J. JESTECH 2016, 19, 1593-1599. [CrossRef]

5. Gecu, R.; Karaaslan, A. Casting temperature dependent wear and corrosion behavior of 304 stainless steel reinforced A356 aluminium matrix bimetal composites fabricated by vacuum-assisted melt infiltration casting. Wear 2020, 446, 203183. [CrossRef]

6. Gronostajski, J.Z.; Kaczmar, J.W.; Marciniak, H.; Matuszak, A. Direct recycling of aluminium chips into extruded products. J. Mater. Process. Technol. 1997, 64, 149-156. [CrossRef]

7. Enayati, M.H.; Bafandeh, M.R.; Nosohian, S. Ball milling of stainless steel scrap chips to produce nanocrystalline powder. J. Mater. Sci. 2007, 42, 2844-2848. [CrossRef]

8. Rofman, O.V.; Prosviryakov, A.S.; Mikhaylovskaya, A.V.; Kotov, A.D.; Bazlov, A.I.; Cheverikin, V.V. Processing and Microstructural Characterization of Metallic Powders Produced from Chips of AA2024 Alloy. JOM 2019, 71, 2986-2995. [CrossRef] 
9. Yussoff, S.B.; Nor, N.H.M.; Husain, H.; Alam, S. Characterisation of recycled aluminium swarf into fine powder for MIM applications via ball milling. J. Mech. Eng. 2019, 8, 164-175.

10. Samuel, M. A new technique for recycling aluminium scrap. J. Mater. Process. Technol. 2003, 135, 117-124. [CrossRef]

11. Susniak, M.; Karwan-Baczewska, J.; Dutkiewicz, J.; Grande, M.A.; Rosso, M. Structure investigation of ball milled composite powder based on $\mathrm{AlSi}_{5} \mathrm{Cu}_{2}$ alloy chips modified by sic particles. Arch. Metall. Mater. 2013, 58, 437-441. [CrossRef]

12. Canakci, A.; Varol, T. A novel method for the production of metal powders without conventional atomization process. J. Clean. Prod. 2015, 99, 312-319. [CrossRef]

13. Godinho, S.C.; Farinha, A.R.; RTrindade, B.; Vieira, M.T. From Chips to Powder Using Ball Milling. In Proceedings of the Euro PM 2014, Salzburg, Austria, 21-24 September 2014.

14. Mendonca, C.S.P.; Dias, A.N.O.; Melo, M.; Ribeiro, V.A.S.; da Silva, M.R.; Oliveira, A.F.; Silva, G. Evaluation of high-energy milling efficiency in stainless steel with addition of vanadium carbides. Int. J. Adv. Manuf. Technol. 2018, 95, 3093-3099. [CrossRef]

15. Mendonca, C.; Capellato, P.; Bayraktar, E.; Gatamorta, F.; Gomes, J.; Oliveira, A.; Sachs, D.; Melo, M.; Silva, G. Recycling Chips of Stainless Steel Using a Full Factorial Design. Metals 2019, 9, 842. [CrossRef]

16. Razumov, N.G.; Masaylo, D.V.; Silin, A.O.; Borisov, E.V.; Ozerskoy, N.E.; Goncharov, I.S.; Popovich, A.A. Investigation of additive manufacturing from the heat-resistant steel powder produced by recycling of the machining chips. J. Manuf. Process. 2021, 64, 1070-1076. [CrossRef]

17. Ruhiyuddin, M.Z.; Faizul, C.P.; Murizam, D.; Nazri, A.R.M. Study on Milling Periods on the Iron Mill Scale Particle Size and Properties. Adv. Mater. Res. 2012, 626, 1001-1005. [CrossRef]

18. Recep Onur Uzun, H.D. Effect of Mill Type on Morphology of AA6013 Aluminium Powder. Revistamateria 2016, 21, 647-655.

19. Emadinia, O.; Vieira, M.T. Application of Disk Milling to Produce Metal Powder from Industrial Chips. In Proceedings of the Euro PM 2020, Lisbon, Portugal, 5-7 October 2020; p. 5.

20. Suryanarayana, C. Mechanical alloying and milling. Prog. Mater. Sci. 2001, 46, 1-184. [CrossRef]

21. Huynh Xuan, K.; Sunwoo, B.; Sangwon, B.; Byeong-woo, K.; Ji Soon, K. Planetary Ball Mill Process in Aspect of Milling Energy. J. Korean Powder Metall. Inst. 2014, 21, 155-164.

22. Fullenwider, B.; Kiani, P.; Schoenung, J.M.; Ma, K.K. Two-stage ball milling of recycled machining chips to create an alternative feedstock powder for metal additive manufacturing. Powder Technol. 2019, 342, 562-571. [CrossRef]

23. Afshari, E.; Ghambari, M. Characterization of pre-alloyed tin bronze powder prepared by recycling machining chips using jet milling. Mater. Des. 2016, 103, 201-208. [CrossRef]

24. Mahboubi Soufiani, A.; Enayati, M.H.; Karimzadeh, F. Fabrication and characterization of nanostructured $\mathrm{Ti}_{6} \mathrm{Al}_{4} \mathrm{~V}$ powder from machining scraps. Adv. Powder Technol. 2010, 21, 336-340. [CrossRef]

25. Verma, P.; Saha, R.; Chaira, D. Waste steel scrap to nanostructured powder and superior compact through powder metallurgy: Powder generation, processing and characterization. Powder Technol. 2018, 326, 159-167. [CrossRef]

26. Umeda, J.; Mimoto, T.; Imai, H.; Kondoh, K. Powder Forming Process from Machined Titanium Chips via Heat Treatment in Hydrogen Atmosphere. Mater. Trans. 2017, 58, 1702-1707. [CrossRef]

27. Soufiani, A.M.; Enayati, M.H.; Karimzadeh, F. Mechanical alloying behavior of Ti6Al4V residual scraps with addition of $\mathrm{Al}_{2} \mathrm{O}_{3}$ to produce nanostructured powder. Mater. Des. 2010, 31, 3954-3959. [CrossRef]

28. Mendonca, C.D.; Oliveira, A.F.; Oliveira, L.A.; da Silva, M.R.; Melo, M.; Silva, G. Structural and Magnetic Properties of Duplex Stainless steel (UNS S31803) Powders Obtained by high Energy Milling of Chips with Additions of NbC. Mater. Res. Ibero-Am. J. Mater. 2018, 21. [CrossRef]

29. Tuncay Dikici, M.S. Effects of disc milling parameters on the physical properties and microstructural characteristics of $\mathrm{Ti}_{6} \mathrm{Al}_{4} \mathrm{~V}$ powders. J. Alloys Compd. 2017, 723, 395-400. [CrossRef]

30. Nazari, K.A.; Rashid, R.A.R.; Palanisamy, S.; Xia, K.; Dargusch, M.S. A novel Ti-Fe composite coating deposited using laser cladding of low cost recycled nano-crystalline titanium powder. Mater. Lett. 2018, 229, 301-304. [CrossRef]

31. Shial, S.R.; Masanta, M.; Chaira, D. Recycling of waste Ti machining chips by planetary milling: Generation of Ti powder and development of in situ TiC reinforced Ti-TiC composite powder mixture. Powder Technol. 2018, 329, 232-240. [CrossRef]

32. Ustundag, M.; Varol, R. Comparison of a commercial powder and a powder produced from Ti-6Al-4V chips and their effects on compacts sintered by the sinter-HIP method. Int. J. Miner. Metall. Mater. 2019, 26, 878-888. [CrossRef]

33. Cherkasova, M.; Samukov, A.; Goncharov, I.; Mezenin, A. Influence of the metal chips disintegration method on the physical and mechanical properties of metal powders obtained. Vibroeng. Procedia 2020, 32, 32-37. [CrossRef]

34. Fullenwider, B.; Kiani, P.; Schoenung, J.M.; Ma, K. From Recycled Machining Waste to Useful Powders for Metal Additive Manufacturing. In Rewas 2019; Springer: Cham, Switzerland, 2019; pp. 3-7. [CrossRef]

35. Godinho, S.C.; Santos, R.F.; Vieira, M.T. In the search of nanocrystallinity in tool-steel chips. Cienc. Tecnol. Dos Mater. 2017, 29, E62-E64. [CrossRef]

36. Santos, R.F.; Farinha, A.R.; Rocha, R.; Batista, C.; Vieira, M.T. High-speed machining tool-steel chips as an outstanding raw material for indirect additive manufacturing? Results Mater. 2021, 100207. [CrossRef]

37. Claudiney, M.; Adhimar, O.; Daniela, S.; Patricia, C.; Vander, R.; Mateus, J.; Mirian, M.; Gilbert, S. A New Method to Recycle Stainless-Steel Duplex UNS S31803 Chips. Metals 2018, 8, 546. [CrossRef]

38. Andrade, A. A manufatura aditiva. Ciência Tecnol. Dos Mater. 2020, 32-2, 11-13. 
39. Brika, S.E.; Letenneur, M.; Dion, C.A.; Brailovski, V. Influence of particle morphology and size distribution on the powder flowability and laser powder bed fusion manufacturability of Ti-6Al-4V alloy. Addit. Manuf. 2020, 31. [CrossRef]

40. Simon Hoegesa, A.Z.a.C.S. Additive manufacturing using water atomized steel powders. Met. Powder Rep. 2017, 72, 111-117. [CrossRef] 